\title{
ANALISIS KADAR PROTEIN CACING LAOR (POLYCHAETA) DARI PERAIRAN PULAU AMBON
}

\author{
Sintje Liline \\ Staf Pengajar Pendidikan Biologi, FKIP-Universitas Pattimura \\ E-mail: sinline28@gmail.com
}

\begin{abstract}
Background: Laor is a variety of types of marine worms (Polychaeta) that appear periodically in large numbers at sea level at any given time and consumed by the Ambon island community. Environmental factors that affect Laor's presence are light, salinity, and temperature. Laor lives on a rocky substrate such as those found in the waters of the village of Latuhalat, the village of Allang, and the village of Hutumuri.

Method: The method used to analyze the protein content of Laor worm is Kjedhal method and the data is analyzed with nonparametric statistic, and if different then further test is done by using LSD (Least Significance Difference) test.

Results: At the time of Laor sampling in the village of Latuhalat, Allang village, and Hutumuri village, wavy surface conditions, water in low tide, the weather is sunny, and the three villages have sandy coral substrate. While the environmental chemical physics factor in Latuhalat village shows salinity is $33^{\circ} /$ $\circ \circ$, temperature is $30^{\circ} \mathrm{C}$, and $\mathrm{pH}$ is 5.23. Allang Village has a salinity of $30^{\circ} / 0 \circ$, a temperature of $29^{\circ} \mathrm{C}$, and a pH of 7.55. The village of Hutumuri has a salinity of $320 / 00$, a temperature of $28^{\circ} \mathrm{C}$, and a pH of 5.50. The results of protein content analysis showed that the average Laor protein level from Latuhalat village was $14.293 \%$, Allang village $15.0497 \%$, and Hutumuri village $10.952 \%$. While the average protein level in Laor worms showed Laor worm protein levels from each village were significantly different.

Conclusion: The average of Laor worm protein from Ambon Island waters is significantly different from that of Latuhalat $14.293 \%$, alang $15.0497 \%$ village, and Hutumuri village $10.952 \%$. The average Laor worm protein level tested with parametric statistic showed Laor worm protein levels from each village were significantly different.
\end{abstract}

Keywords: Laor, Protein Content, Ambon Island

\begin{abstract}
Abstrak
Latar Belakang: Laor adalah berbagai jenis cacing laut (Polychaeta) yang muncul secara berkala dalam jumlah yang besar di permukaan laut pada waktu tertentu dan dikonsumsi oleh masyarakat pulau Ambon. Faktor lingkungan yang mempengaruhi kehadiran Laor adalah cahaya, salinitas, dan suhu. Laor hidup pada substrat berkarang seperti yang terdapat pada perairan desa Latuhalat, desa Allang, dan desa Hutumuri.

Metode: Metode yang digunakan untuk menganalisis kadar protein pada cacing Laor adalah metode Kjedhal dan data dianalisis dengan statistic nonparametric, dan jika berbeda maka dilakukan uji lanjut dengan menggunakan uji LSD (Least Significance Difference).

Hasil: Pada saat pengambilan sampel Laor di desa Latuhalat, desa Allang, dan desa Hutumuri, kondisi permukaan air bergelombang, air dalam kondisi mulai surut, cuacanya cerah, dan ketiga desa memiliki substrat karang berpasir. Sedangkan faktor fisika kimia lingkungan di desa Latuhalat menunjukan salinitas adalah $33 \%$, suhu adalah $30^{\circ} \mathrm{C}$, dan pH adalah 5,23 . Desa Allang memiliki salinitas $30 \%$, suhu $29^{\circ} \mathrm{C}$, dan $\mathrm{pH} 7,55$. Desa Hutumuri memiliki salinitas $32 \%$, suhu $28^{\circ} \mathrm{C}$, dan pH 5,50. Hasil analisis kadar protein menunjukkan bahwa, rata-rata kadar protein Laor dari desa Latuhalat $14.293 \%$, desa Allang $15.0497 \%$, dan desa Hutumuri $10.952 \%$. Sedangkan rata-rata kadar protein pada cacing Laor menunjukkan kadar protein cacing Laor dari setiap desa berbeda nyata.

Kesimpulan: Rata-rata kadar protein cacing Laor dari perairan pulau Ambon berbeda nyata yaitu yang berasal dari desa Latuhalat $14.293 \%$, desa alang $15.0497 \%$, dan desa Hutumuri $10.952 \%$. Rata-rata kadar protein cacing Laor yang diuji dengan statistic parametric menunjukkan kadar protein cacing Laor dari setiap desa berbeda nyata.
\end{abstract}

Kata Kunci: Laor, Kadar Protein, Pulau Ambon 


\section{PENDAHULUAN}

Masyarakat Maluku khususnya pulau Ambon sejak dahulu telah mengenal dan mengkonsumsi cacing laut (Polychaeta) dan menyebutnya Laor. Laor adalah salah satu biota khas perairan Maluku (Radjawane, 1982) dan juga dikenal dengan nama cacing Wawo yang muncul ke permukaan perairan sebanyak satu kali dalam setahun yaitu pada bulan Maret atau April, dimalam purnama atau beberapa hari setelahnya (Pamungkas, 2009b). Biota laut ini muncul untuk melakukan swarming, yakni peristiwa ketika cacing laut dari jenis tertentu berkerumun dalam jumlah melimpah di sekitar permukaan air untuk melakukan perkawinan secara eksternal. Waktu itu, dengan menggunakan seser tradisional, hewan ini biasanya ditangkap oleh penduduk lokal di pantai-pantai berkarang guna dijadikan bahan pangan tradisional (Pamungkas, 2009a).

Faktor yang mendukung kehadiran Laor, didorong oleh pasang surut air laut dan kadar garam. Kehadirannya untuk reproduksi karena pengaruh transisi musim dari panas (barat) ke musim hujan (timur). Faktor lingkungan yang mempengaruhi kehidupan Laor adalah cahaya dan suhu optimum yang relatif rendah. Selain itu, Laor adalah hewan yang hidup berkoloni dan harus tetap berada di lingkungan air laut dengan kadar garam yang tinggi agar tidak membusuk (Radjawane, 1982).

Polychaeta dapat hidup di berbagai habitat seperti pada dasar berlumpur, berpasir, dan berbatu (Yusron, 1985). Cacing laut Polychaeta dapat mendiami substrat keras berupa karang dalam jumlah yang besar (Nybaken, 1992). Perairan desa Latuhalat, desa Alang, dan desa Hutumuri di pulau Ambon merupakan daerah perairan yang substratnya berkarang dan menjadi tempat hidup Laor. Desa Latuhalat di kecamatan Nusaniwe kota Ambon, desa Alang di kecamatan Leihitu kabupaten Maluku Tengah, dan desa Hutumuri di kecamatan Leitimur Selatan kota Ambon.

Selama ini masyarakat desa Latuhalat, desa Allang, dan desa Hutumuri memanfaatkan Laor sebagai bahan pangan tradisional yang dipercaya kaya protein. Laor yang dikonsumsi adalah bagian posterior berupa epitoke jantan dan epitoke betina yang berisi sel telur dan sel sperma sehingga berpotensi mengandung protein (Pamungkas, 2009a). Kadar protein pada Laor dari desa-desa yang berbeda ini perlu dibuktikan dengan cara analisis protein.

\section{MATERI DAN METODE}

Pengumpulan sampel berupa Laor dari perairan pulau Ambon di desa Latuhalat kecamatan Nusaniwe kota Ambon, desa Allang kecamatan Leihitu kabupaten Maluku Tengah, dan desa Hutumuri kecamatan Leitimur Selatan kota Ambon dilakukan pada Maret 2012. Pengumpulan menggunakan seser tradisional (jaring) untuk mengambil Laor dari air laut, dibilas dengan air bersih dan dimasukkan ke dalam botol sampel dan disimpan di dalam Frezer.

Pada saat pengambilan sampel penelitian dilakukan pengamatan dan pengukuran faktor fisika kimia lingkungan. Pengamatan berupa pengamatan kondisi permukaan air, kondisi pasang surut, cuaca, dan substrat. Pengukuran faktor fisika kimia lingkungan berupa salinitas air laut dengan refractometer, suhu air laut dengan termometer, dan $\mathrm{pH}$ air laut dengan $\mathrm{pH}$ meter.

Analisis kadar protein dilakukan berdasarkan metode Kjedhal. Metode ini merupakan metode yang sederhana untuk penetapan nitrogen total pada asam amino, protein, dan senyawa yang mengandung nitrogen. Sampel didestruksi dengan asam sulfat dan dikatalisis dengan katalisator yang sesuai sehingga akan menghasilkan amonium sulfat. Setelah pembebasan alkali dengan kuat, amonia yang terbentuk disuling uap secara kuantitatif ke dalam larutan penyerap dan ditetapkan secara titrasi.

Kadar protein dihitung dengan persamaan berikut:

$$
\begin{aligned}
\begin{array}{l}
\text { Kadar } \\
=
\end{array} & \frac{\text { N NaOH blanko }-V \mathrm{NaOH} \text { sampel }}{\text { Berat Sampel }(\mathrm{mg})} \times \\
& \quad \mathrm{NaOH} \times 14,008 \times 100 \% \times \mathrm{Fk}
\end{aligned}
$$

Keterangan: Fk : faktor koreksi; Fk N : 16

Data yang diperoleh dianalisis dengan menggunakan statistic nonparametric dan dilanjutkan dengan uji lanjut LSD (Least Significance Difference). 


\section{HASIL DAN PEMBAHASAN}

\section{Pengambilan Cacing Laor}

Proses pengambilan cacing Laor di desa Latuhalat, desa Alang dan desa Hutumuri dilaksanakan pada hari yang sama yaitu pada malam hari tanggal 10 Maret 2012 karena waktu pemunculan cacing Laor yang hanya terjadi sekali dalam setahun.
Pengamatan terhadap kondisi perairan dan pengukuran faktor fisika kimia lingkungan berupa kondisi permukaan air, kondisi pasang surut, cuaca, substrat, salinitas, suhu, dan $\mathrm{pH}$ air laut yang disajikan pada tabel 1.

Tabel 1. Faktor Fisika-Kimia Lingkungan di Perairan Pulau Ambon

\begin{tabular}{llll}
\hline \multicolumn{1}{c}{ Parameter } & \multicolumn{1}{c}{ Latuhalat } & \multicolumn{1}{c}{ Allang } & \multicolumn{1}{c}{ Hutumuri } \\
\hline Kondisi Permukaan Air & Gelombang & Gelombang & Gelombang \\
Kondisi Pasang Surut & Mulai surut & Mulai surut & Mulai surut \\
Cuaca & Cerah & Cerah & Cerah \\
Substrat & Karang dan pasir & Karang dan pasir & Karang dan pasir \\
Salinitas & $33 \% \circ$ & $30 \% \circ$ & $32 \% \circ$ \\
Suhu & $30{ }^{\circ} \mathrm{C}$ & $29{ }^{\circ} \mathrm{C}$ & $28^{\circ} \mathrm{C}$ \\
pH & 5,23 & 7,55 & 5,50 \\
\hline
\end{tabular}

Pengamatan kondisi perairan dan pengukuran faktor fisika kimia lingkungan menunjukan bahwa pada saat pengambilan sampel Laor di desa Latuhalat, desa Alang, dan desa Hutumuri memiliki kondisi permukaan air bergelombang, air dalam kondisi mulai surut, cuacanya cerah, dan ketiga desa memiliki substrat karang berpasir. Sedangkan faktor fisika kimia lingkungan di desa Latuhalat menunjukan salinitas adalah $33 \%$, suhu adalah $30^{\circ} \mathrm{C}$, dan $\mathrm{pH}$ adalah 5,23. Desa Alang memiliki salinitas $30 \%$, suhu $29^{\circ} \mathrm{C}$, dan $\mathrm{pH} 7,55$. Desa Hutumuri memiliki salinitas $32 \%$, suhu $28^{\circ} \mathrm{C}$, dan $\mathrm{pH} 5,50$.

Radjawane (1982) menjelaskan bahwa salinitas optimum untuk kehidupan cacing Polychaeta adalah sekitar $33 \%$. Salinitas yang tinggi ini menjaga segmen tubuh Polychaeta dari pembusukan. Adaptasi pada daerah bersalinitas tinggi yang menyebabkan Polychaeta tidak ditemukan di semua perairan walaupun perairan tersebut memiliki substrat karang.

Latumahina (2011) melaporkan bahwa parameter fisika-kimia di desa Latuhalat pulau Ambon yang menjadi salah satu tempat hidup Laor memiliki suhu berkisar $27^{\circ} \mathrm{C}$, salinitas $32 \%$, pH 8,10, dan DO 5,9.

\section{Kadar Protein}

Hasil analisis rata-rata kadar protein Laor yang berasal dari desa Latuhalat sebesar $14.293 \%$, desa Allang sebesar $15.0497 \%$, dan desa Hutumuri sebesar $10.952 \%$. Rata-rata kadar protein cacing Laor yang diuji dengan statistic non parametric menunjukkan kadar protein cacing Laor dari setiap desa berbeda nyata dapat dilihat pada tabel 2 dan gambar 1 .

Tabel 2. Rata-rata Kadar Protein Laor dari Perairan Pulau Ambon.

\begin{tabular}{ll}
\hline \multicolumn{1}{c}{ Area } & \multicolumn{1}{c}{ Kadar Protein (\%) } \\
\hline Latuhalat & $14.293 \pm 0.165^{\mathrm{a}}$ \\
Allang & $15.0497 \pm 0.316^{\mathrm{b}}$ \\
Hutumuri & $10.952 \pm 0.516^{\mathrm{c}}$ \\
\hline
\end{tabular}

Keterangan: ${ }^{a, b, c} p<0,05$ 


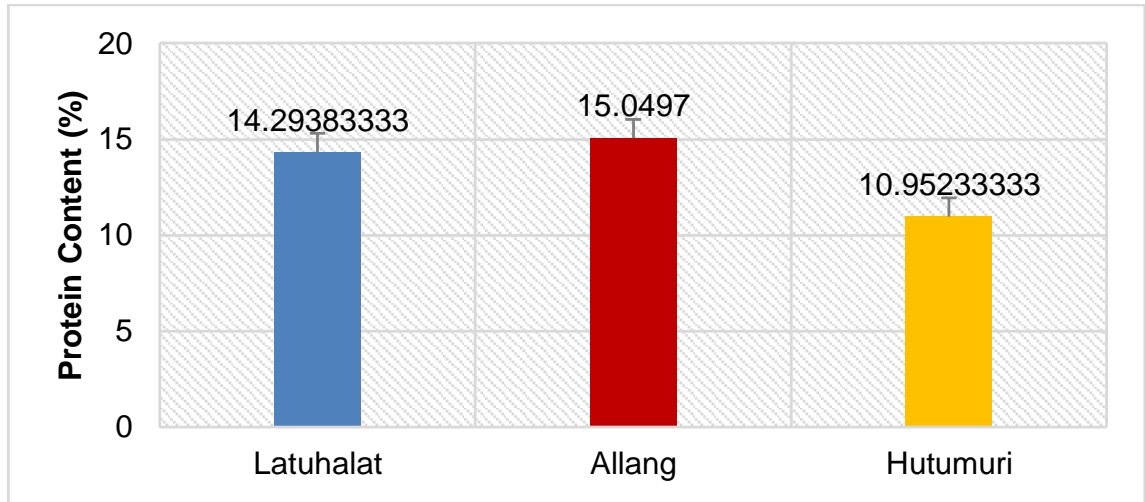

\section{Gambar 1. Histogram Rata-rata Kadar Protein Laor Dari Perairan Pulau Ambon.}

Laor yang dikonsumsi masyarakat pulau Ambon mengandung nilai gizi yang tinggi. Ini dibuktikan dengan penelitian yang dilakukan oleh Radjawane (1982) terhadap sampel Laor 1-2 gram ternyata mengandung protein sebanyak $31,15 \%$, karbohidrat sebanyak $0,41 \%$, kadar glukosa sebanyak 0, 432\%, dan kadar lemak sebanyak $7,76 \%$. Selain itu Laor juga mengandung vitamin B-12. Kandungan gizi Laor lebih tinggi apabila dibandingkan dengan sampel tepung ikan sebanyak 1-2 gram diperoleh kadar proteinnya $10,39 \%$, kadar karbohidrat $0,41 \%$, dan kadar lemak $7,32 \%$.

Tampubolon, dkk. (2007) memperoleh kadar protein dari Laor (Eunice viridis) segar seberat 1 gram dari perairan Maluku sebanyak 13,73\%. Savitri, dkk. (2008) meneliti sampel Laor yang diambil di desa Latuhalat di pulau Ambon dan desa Wearlilir di kepulauan Kei masing-masing seberat 1 gram ternyata mengandung protein sebanyak $13,92 \%$ dan $13,85 \%$. Latumahina (2011) membuktikan bahwa Laor yang berasal dari perairan desa Latuhalat di pulau Ambon megandung kadar protein 13,92\%. Pamungkas (2015) meneliti sampel Laor kering yang terdiri atas epitoke betina dari perairan pulau Ambon sebanyak 2 gram ternyata mengandung kadar protein kasar sebanyak $54,72 \%$.

Hasil penelitian yang dilaporkan oleh Miller and Pen (1959) membuktikan bahwa minat orang Samoa dan Fiji untuk memanen cacing laut jenis Palolo di negara mereka karena analisis membuktikan Palolo memiliki nilai gizi yang tinggi. Palolo memiliki 15\% protein dibandingkan dengan sekitar 20\% protein yang terdapat dalam daging sapi, selain itu kadar lemak sekitar setengah dari lemak pada daging sapi. Palolo memiliki tiga kali lebih banyak kalsium, sekitar dua kali fosfor dan zat besi yang sama pada daging sapi.

\section{KESIMPULAN}

Kesimpulan yang dapat dikemukakan berdasarkan hasil penelitian yang dilakukan adalah hasil analisis rata-rata kadar protein cacing Laor dari perairan pulau Ambon berbeda nyata yaitu yang berasal dari desa Latuhalat $14.293 \%$, desa alang $15.0497 \%$, dan desa Hutumuri 10.952\%. Rata-rata kadar protein cacing Laor yang diuji dengan statistic non parametric menunjukkan kadar protein cacing Laor dari setiap desa berbeda nyata.

\section{DAFTAR RUJUKAN}

Latumahina, M. Ch. A., Pengolahan dan Komposisi Gizi Cacing Polychaeta di Pulau Ambon, Prosiding PERMAMA, 2011, 1, 1, 247-254.

Miller, C. D. \& Pen, F., Composition and nutritive Value of Palolo. Pacific Science, 1959, 13, 191-194.

Nybakken, J. W., 1992. Biologi Laut Suatu Pendekatan Ekologis. Gramedia, Jakarta, 1992, 334.

Pamungkas, J.(a), Pengamatan Jenis Cacing Laor (Annelida, Polychaeta) di Perairan Desa Latuhalat Pulau Ambon, dan Aspek Reproduksinya, Jurnal Triton, 2009, 5, 2, 1-10.

Pamungkas, J.(b), Swarming Cacing Laut Polikhaeta (Annelida) di Indonesia, Jurnal Oseana, 2009, 34, 3, 35-44. 
Pamungkas J., Species richness and macronutrient content of wawo worms (Polychaeta, Annelida) from Ambonese waters, Maluku, Indonesia, Biodiversity Data Journal, 2015, 3: e4251. doi: 10.3897/bdj.3.e4251

Radjawane TR., Laor: Cacing Laut Khas Perairan Maluku, Lomba Karya Penelitian IImiah Remaja, Jakarta. Departemen Pendidikan dan Kebudayaan Republik Indonesia, Jakarta, 1982, 1- 29.

Savitri, I. R. E., Latumahina, M. Ch. A., \& Tapotubun, A. M. Studi Kandungan Gizi
Laor. Prosiding Seminar Nasional Perikanan dan Kelautan, Fakultas Perikanan dan Kelautan Universitas Brawijaya Malang, 2008, 154-156.

Tampubolon, K., Purnomo, D., \& Sangadji, M. 2007. Pengolahan Pasta Laor (Eunice viridis) dengan berbagai Konsentrasi Garam. Buletin Teknologi Hasil Perikanan, 2007, 10, 1, 47-58.

Yusron, E., Beberapa Catatan Mengenai Cacing Laut (Polychaeta), Jurnal Oseana, 1985, 10, 4, 122-127. 